\title{
Criticism and Reconstruction of Visual Metaphor to Art Ethics from the Perspective of Popular Art*
}

\author{
Wei Guo \\ College of Chinese Language and Literature \\ Henan University \\ Kaifeng, China 475001
}

\begin{abstract}
The structure of visual metaphor is the vane of observing the art ethic problems. Around it, we can observe the basic relationship of art, including the relationships of autonomy and heteronomy, art and reality, sensibility and reason, and how could them keep balance under certain tension, thus construct a set of reasonable and standardized system of theory for ethnic issues of art from interior of visual art. From the perspective of visual metaphor, the relationship between art autonomy and art heteronomy is diverse. Visual metaphor is the regulator of visual artistic autonomy and artistic heteronomy, and the type and mode of visual metaphor are the windows to observe the realization of art ethnic spirits. From these two angles, the essence of the ethnic issue of popular art is to reconstruct reason and space order of art and remold rituality of art on the basis of catering emotional catharsis of viewers and respecting the human instinct desire, thus keep people and works with both cooperation and a distance, and open up a wide space for heteronomy entering art.
\end{abstract}

Keywords—visual metaphor; popular art; art ethics; criticism; reconstruction

\section{INTRODUCTION}

Just What Is It that Makes Today's Homes So Different, So Appealing? is a collage created by artist Richard Hamilton in 1956. It makes the question of the essence of art replaced from "what is art" into "what makes art", which opened the prelude to the flourishing of post-modern popular art (daily life aestheticization) for the history of Western art. Since then, all kinds of avant-garde art styles were diverse and emerged in endlessly. But behind this lively and prosperous surface, it reflected deep ethical values and moral problems. At present, Chinese contemporary art is also in the process of daily life adaptation and popularization, which is increasingly impacting people's moral, psychological bottom line and even visual endurance. In the face of this situation, people cannot help asking "What should art do? What is the use of art?". In order to answer the two questions, we should have a more sober understanding of the relationship between visual metaphor and artistic autonomy and artistic ethics (the key part of the connotation of art heteronomy).

*This thesis is a phased achievement of Henan Philosophy and Social Sciences Planning Project (2017BYS004).

\section{Visual METAPHOR, THE REgUlatoR OF ART AUTONOMY AND ART ETHICS}

The evolution of the artistic style is the change and replacement of the synchronic metaphorical elements ${ }^{1}$ and metaphorical patterns at the diachronic level after combing, as well as a constant pursuit course of artists for relatively stable structural mode in the deviation ${ }^{2}$ of realist function of picture. As the representation of the artistic style, the visual metaphor also reflected adjustment of deep structure of human thinking for specific use in different periods. The rise and decline of visual metaphor, as life entity, has provided a solid theoretical basis for the study of the stage of art history from the evolution of visual metaphor, a contact point for the analysis of art autonomy and art ethnics from the interior of visual art.

Based on this, we believe that the structure of visual metaphor is the vane of observing ethic issues of art. Around it we can observe the basic relationship of art, including the relationships of autonomy and heteronomy, art and reality, sensibility and reason, and how could them keep balance under certain tension, thus construct a set of reasonable and standardized system of theory for ethnic issues of art from interior of visual art.

From the perspective of visual thinking, the foundation of the generation of visual metaphor is the result of highlighting similarity between free field and perceptual field ${ }^{3}$. This

Because the synchronic performance and diachronic changes of the artistic style are the external manifestation of visual metaphor for specific use. Its internal motivations are alterations of metaphor mode formed on the basis of four metaphor elements, sensuous image, double vision, analogy and animistic projection. See [American] Rene. Wellek and Austen. Warren: Literary Theory, translated by Liu Xiangyu et al. Sanlian Bookstore, 1984 edition, Page 215.

If we regard the verbal metaphor as a deviation from the meaning of the language convention and the daily usage, then the visual metaphor is a deviation from the realistic meaning of the image, or, "the metaphorical image involves a deliberate violation of the universally recognized standard description pattern." [French] Paul-Ricoeur: Living Metaphor, translated by Wang Tangjia, Shanghai Translation Publishing House, 2004 edition, Page 17

The field is "a system that is adjusted and stereotyped by the various objective forces (whose way is like a magnetic field), a form of relation that is given a particular gravitational force which is imposed on all the objects and actors that enter the field." [French] Pierre Bourdieu and Wacquant: Practice and Reflection - Introduction to Reflective Sociology, translated by Li Kang and Li Meng, Central Compiling Press, 2004 edition, Page 138. As a basic concept of visual metaphor analysis in this thesis, it is 
perceptual field uses specific symbols as the intermediary to realize the communication and dialogue between artist and viewers, and to complete the adjustment of the visual metaphor to the autonomy and the heteronomy.

On the one hand, visual metaphor is the representation of the artistry of visual art, and the formation process of visual metaphor is essentially the process of artistic autonomy. Visual metaphor is realized by the concrete representation symbols of visual art. In other words, by transforming symbols into noumenon and metaphor, illusion presentation is given by using the similarity or creating similarity between them in visual art: the elements of the image symbols are consistently constructed on theme because of compositionality (integration or aggregation) of space, identity of time or succession of time. In other words, the constituent elements of visual metaphor have the nature of "cannot coexist at the same time" ${ }^{4}$ in accordance with the law of nature, and visual metaphor exists as a function. Through semantic integration and governing function, it first breaks the accustomed intercourse between things, and then organizes various elements into a comprehensive and integral or analytical and composed artistic works at the symbolic level. This process is the process of self recognition of visual metaphor image symbols, the formation process of visual art, the process of art autonomy and the unity and superposition of three processes.

On the other hand, visual metaphor is the key to realizing art heteronomy. In the mechanism of art heteronomy, the intention of artists is an important factor that directly influences and restricts the realization of artistic ethic spirit. As the visual art symbols have features of significance deviation, transfer or cruising and may reflect uninterpretability or deconstruction, artists often adjust the constructing way or the internal structure of visual metaphor in order to maintain a moderate balance between the explicit and obscure meanings of art. For example, when the perceptual emotion in visual art is out of control, the artist's appeal for interference of ethical heteronomy, in fact, is to emphasize and increase the restraining effect of reason in the process of the reconstruction of space order, with the restructure of visual metaphor as the core. At the same time, when art autonomy in visual art gradually strip out heteronomy factors loaded in art and tends to be unpopular self-reference state, visual metaphor began to call on the ethical factors in the art heteronomy to renew the value criticism and restructure in order to close the distance between art and real life.

As art ethics is an important part of the connotation of art heteronomy, it can be said that visual metaphor is also a regulator between visual art autonomy and art ethics. Based on this, we can say that the type and mode of visual metaphor is the window to observe the realization of art ethic spirit, because the type of visual metaphor can provide basic observation path to verify and examine how art ethnic achieve regulation between autonomy and heteronomy through visual metaphor. First, although the basic visual elements in visual

the relationship structure formed by the mutual restriction, interaction and balance of various forces including human nature.

[American] Noel Carol: Transcendental Aesthetics, translated by Li Yuanyuan and Gao Jianping, Commercial Press, 2006 edition, Page 571. metaphor are the concrete means of forming art autonomy, the three subject assignment categories in visual metaphor are the specific ways for visual art heteronomy to intervene. Second, divide two types of visual metaphor, pure visual metaphor and "picture-with-text" intertextual visual metaphor, according to the spatial representation of noumenon and metaphor in the specific visual art works, and they are two actual manifestations of art autonomy and art heteronomy in confrontation or adaptation. Third, from the specific visual metaphorical types of avant-garde art in the early and prosperous period of modernism, we can know that the ethical issues involved are mainly caused by over high proportions of irrational category metaphor and meta-metaphor preventing or rejecting rational category metaphor.

From the perspective of visual metaphor, the relationships between art autonomy and art heteronomy are diverse. The relationships of art autonomy and art heteronomy include opposite relations, dialectical relations, compromise relations and absolute ethical supremacy. In the specific art practice, the relationships of them are more complicated. We know that the function transformation from expression mode and speech figures to art representation form and cultural practice mode, and then to visual thinking way reflects that visual metaphor is the key for Western avant-garde art changing from revolutionary avant-garde to avant-garde passivation. It has reflected the transcendence of art autonomy to art heteronomy in visual metaphor. The development course of Chinese contemporary art, from traditional freehand ink and water painting to revolutionary realism, and then to criticizing modern and post modern eclecticism has revealed the ambiguous relationship between art autonomy and art heteronomy in the visual metaphor.

Contemporary art ethics must gradually learn to use visual metaphor as a regulator, so as to make art come back to the core of human nature and true need of man under the role of art autonomy, and overcome unprecedented crisis in evolution course of avant-garde art caused by rising art autonomy. Under certain conditions, the intervention of art ethics is the original motive force that it gives art when it is opposite to art autonomy, and art produces its artistry when it resists the society. This is because "the sociality of art is mainly because it stands on the opposite side of society. But art with opposite feature will only emerge when it becomes a self-disciplined work." Based on this, contemporary art can take a variety of possibilities through the reflection and resistance of the aesthetic subject and art itself, and the reverse manipulation of art autonomy to technology and capital.

\section{The REVAluation OF Popular ART VAluE}

When the avant-garde art was thoroughly rethought and questioned by the radical aesthetic edge in the modernist period, the post-modern popular art surged in a derogatory voice. After that, in fields of TV, film, best-selling novel or experimental drama, pop music, street dance, animated cartoon, comic cartoon, creative advertising and so on, the consumption orientation of kitsch and amusement-to-death is filled with

[Germany] Adorno: Theory of Aesthetics, translated by Wang Keping, Chongqing Press, 1998 edition, Page 386. 
people's daily life. So, many philosophers in the 20th Century had hardly come to their sense for quite a long time, and still built their own theoretical edifice with elegant art as the reference standard. The "non-individualized commodity" theory of American Philosopher and Writer Dwight Macdonald, Clement Greenberg's "negative appreciation", Habermas's theory of "tool rationality" and Adorno and Horkheimer's concept of "cultural industry" and theory of "new sensibility" put forward from the relationships among form, art ethnics and revolution all rejected popular art in different ways and fought against its non-individualization, the supremacy of technical rationality and the function of political enslavement, and tried to use Kant's non-utility utilitarianism and other pure-art aesthetic standards as good remedy to kitsch of popular art with no reflection, homogeneity and stylization and suppressing imagination. However, in spite of criticism and questioning, popular art is still full of every aspect of social life like a single spark starting a prairie fire.

Noel Carol, a contemporary American Art philosopher, tries to construct a philosophy system of popular art while refuting "vulgar art theory". He believes that the aesthetic function of contemporary popular art should be reassessed as follows: first, popular art provides the viewers with the opportunity to vent some emotions, such as fear, suspense, pain, and sexual tension. Secondly, the popular art improves the aesthetic perception and appreciation interest of the masses by reducing or even leveling some pure knowledge structure and weakening halo of artistic interest. Based on this, Carol stressed that we should not stand on the standpoint of negation, take out a set of theoretical system of elite art to criticize it and oppose it, but should uphold the standpoint of "mild morality" 6 and face the ethical problems encountered by art. However, contrary to Carol's theory, Berys Gaut, a contemporary American scholar, insists on an absolute "ethicism"7. In fact, the introduction of art ethics into popular art from any point of view shows that the art autonomy is calling for the intervention of other heteronomous factors, such as moral values, so as to re-find their own art characters.

There is no doubt that the main problem facing contemporary popular art is that while art is in the process of catering, confronting or transcending the ethical threshold pursued by elegant art, the aesthetic perception of people can be returned or universally promoted, but at same time the inner ethical intention has been wandering or even missing. It is manifested in the following aspects: first, the reason of popular art is forced to give way to sensibility, or transformed into a subjective and highly individualized concept, so the distance between human and art works is disappearing. Second, with the pursuit of avant-garde art for art purity, the autonomy mechanism of art once completely overcame heteronomy, ethnic morality and other external mechanism lose efficacy. The space disorder presented by popular art means the anomie of value to some extent. At the same time, due to the enhancement of the trend of media, the visual effect created by

\section{6 [American] Noel Carol: Transcendental Aesthetics, translated by} Li Yuanyuan and Gao Jianping, Commercial Press, 2006 edition, Page 468.

Liu Xiaofei and Yan Tianjie: Study of the Relationship between Art and Morality in the Perspective of Analytical Aesthetics. Philosophy Dynamics, Issue 5, 2010. classical art's heavily relying on "tactile sense" is replaced by the effect of comprehensive sensory perceptual system (vision, sense of touch, smell, hearing, taste and so on). Instead, it makes the popular art present a tendency of excessively pursuing sensory stimulation. Third, the excessive development of artistic independent speech function leads to failure of art explanation. Accordingly, popular art has gradually lost its ability of self reflection and criticism. Thus, as a "pseudo art", it falls into the whirlpool of "nihilism" and "non-depth" that the elitism theorists claim.

We believe that the contemporary popular art can neither go on the road of pure formalism as the avant-garde art of the modernist period blindly pursued art autonomy, nor fall into the theory of art ethics supremacy, thus limiting the freedom and creativity of art, nor ignore art ethic issues or let them be wanton with the ambiguous attitude of the eclecticism.

\section{THE STUdy OF THE RELATIONSHIP BETWEEN ART ETHICS AND ART AUTONOMY}

The relationship between art ethics and art autonomy has always been the core topic in the history of art.

As early as in ancient Greece, Platon declared in his Utopia that visual art must be restricted, whether in realistic animal portraits and buildings, or in other works of art, and artists must be forbidden to reproduce evil, dissolute, vulgar and rude works. Aristotle believed that "the purpose of life belongs to the goodness of the soul, not the external goodness" ${ }^{8}$. Horace advocates that art needs moral knowledge in the active life of moral life. It can be seen that western classical aesthetics advocates that art should bring people the best virtue that is based on reason and constantly transcends its own finiteness. In this period, although art was expelled from the utopia by Platon, this event, in fact, should be understood as a way of restricting the artistic function under the precondition of no complete negation of the role of autonomy in the art. In the Middle Ages, Christian art emphasized the divinity, suppressed or even stifled humanity by advocating the ethical concept of art, and even rationality was regarded as the original sin. In this stage, the strength of art ethics dominated and even suppressed the exertion of artistic heteronomy mechanism, which led to the fact that art once lost the function of self-regulation. In the Renaissance, artists and researchers began to pay attention to the reflection function of art selfdiscipline on art ethics. Rafael, Michelangelo, Da Vinci and other great artists tried a variety of independent artistic styles to break free from religious shackles. Lessing, a theorist, holds that poetry and painting have their own characteristics. Visual arts should express the most inclusive "instant" of 18th Century, Kant advocated pure moral law and "absolute command" ethics. While artists were on the stage of history as

[Ancient Greece] Aristotle: Nico Marco Ethics, Chinese Social Science Press, 1990 edition, Page 13.

9 Lessing believed that the greatest effect of art only existed in "the instant that allows imagination to move freely", because this instant can "get a constant continuity. So, anything that can be thought to be just a fleeting thing should not be shown in that instant." See Lessing: Laocoon, translated by Zhu Guangqian, People's Literature Publishing House, 1984 edition, Page 18,19 . 
"genius", aesthetic criticism and ethical criticism were not related to each other and were independent to each other. It had become a mainstream, and the function of art autonomy began to leap into various artistic phenomena.

Since the 20th Century, modern art practices, such as impressionism, symbolism, surrealism, cubism and abstract expressionism, have sought, questioned or rebelled against the theory of art essence with the attitude of non-stop pioneering with the rise of aesthetic thoughts, such as aestheticism and formalism. Aesthetician even more despised and rejected art ethnic criticism. Art autonomy gradually repressed and broke away from the restriction and regulation of art ethics. "I admire the arrival of the moment that aestheticism takes the place of moral ethics and aesthetic rule of life," ${ }^{10}$ said Oscar Wilde, who deliberately boasts his idealism with "decadent". It can be said that the idea of "art for art" is not so much a mature aesthetic theory, as a slogan for some artists to unite and fight. They are tired of the empty humanitarianism of the Romantics, and feel that they must express their hatred for bourgeois commercialism and vulgar utilitarianism ${ }^{11}$. It follows that the focus of modern western art ethics studies quickly turns to the expression of skepticism, nihilism, pessimism and even decadence in spiritual and moral values. The regulating effect of art ethics is almost completely dissociated and gradually disappeared from the perspective of artists and researchers.

It is a little optimistically that Western Marxism theorists try to examine the complex relationship between art autonomy and ethics from different perspectives, which provided new theories and methods for the study of artistic functions, and produced "dialogue ethics" of Habermas, "rationalization" theory of Marx Weber, and Marcuse's "art autonomy" theory. Philosophers try to reconcile the relations between the two, but these viewpoints and theories have their specific times.

Comparatively speaking, the process of artistic autonomy presented by contemporary popular art has concealed character.

First of all, popular art dispels the introspection of elegant art with entertainment. However, when it gets rid of selfinflection, popular art directly inspired viewers' emotion and the active participation of a variety of sensory systems in the big cultural background. Art is no longer just the image of initiate passively accepted by the public, but rather an equal friend accompanying daily life of the masses. It can be said that art has gone to a new round of rational return - art no longer lingers in such an unsolvable and self-circulating language labyrinth, such as the question of "what is the art", nor does it frown and think the philosophical propositions, such as "what makes art", but directly begins to focus on social topics, such as identity, ethnic group and gender, from the identity of the equal interlocutor and even the direct participant of art form.

Secondly, the art ethic spirit infiltrated in popular art breaks through the limitation of "purification" theory in traditional morality. Artists no longer limit the function of art

\footnotetext{
10 Complete Works of Wilde, Volume 4, edited by Zhao Wuping, Chinese Literature Publishing House, 2000 edition, Page 452.

11 American] Mathay Karenescu: Five Faces of Modernity, translated by Gu Ailin and Li Ruihua, Commercial Press, 2002 edition, Page 51, 52.
}

to how to nurture and cultivate the noble moral sentiment of the viewers, but focus on the natural moral view of the people co-developed with the cooperation with the masses, that is to understand and even comply with human's instinct, sexual desire, love desire, and social appeal as an independent individual under the premise of respecting human nature.

Therefore, although the contemporary popular art still has too many ethical issues to be solved, the multi-philosophy concept it brings to people is particularly noteworthy. Of course, it also includes the diverse relationship of art ethics and art autonomy.

\section{CONCLUSION}

From this point of view, the essence of ethnic issue of popular art is to reconstruct reason and space order of art and remold rituality of art on the basis of catering emotional catharsis of viewers and respecting the human instinct desire, thus keep people and works with both cooperation and a distance, and open up a wide space for heteronomy entering art In this way, through the use of the four elements of visual metaphor and the proper adjustment of the metaphorical mode, the popular art ethics can also timely remind artists to keep a clear boundary among various art forms, so that the work can maintain a certain tension balance between the viewer's comprehensive perception and experience. But this intervention way of art ethics is not a simple return to tradition, but the return and remolding of a higher level of art character after modernity baptism.

\section{REFERENCES}

[1] [American] Rene - Wellek and Austen - Warren: Literary Theory, translated by Liu Xiangyu et al. Sanlian Bookstore, 1984 edition. 【美】勒内·韦勒克、奥斯汀·沃伦 : 《文学理论》，刘象愚等 译, 三联书店 1984 年版。

[2] [French] Paul - Ricoeur: Living Metaphor, translated by Wang Tangjia Shanghai Translation Publishing House, 2004 edition. 【法】保罗.利 科: 《活的隐喻》, 汪堂家译, 上海译文出版社 2004 年版.

[3] [French] Pierre Bourdieu and Wacquant: Practice and Reflection Introduction to Reflective Sociology, translated by $\mathrm{Li}$ Kang and $\mathrm{Li}$ Meng, Central Compiling Press, 2004 edition.【法】皮埃尔. 布迪厄、 华康德 : 《实践与反思一一思社会学导引》, 李康、李猛译, 中央编译出版社 2004 年版。

[4] [American] Noel Carol: Transcendental Aesthetics, translated by Li Yuanyuan and Gao Jianping, Commercial Press, 2006 edition.【美】 诺埃尔. 卡罗尔: 《超越美学》, 李媛媛译, 高建平校, 商务印书 馆 2006 年版,

[5] [Germany] Adorno: Theory of Aesthetics, translated by Wang Keping, Chongqing Press, 1998 edition. 【德】阿多诺: 《美学理论》, 王柯 平译, 重庆出版社 1998 年版。

[6] [American] Noel Carol: Transcendental Aesthetics, translated by Li Yuanyuan and Gao Jianping, Commercial Press, 2006 edition.【美】 诺埃尔. 卡罗尔: 《超越美学》, 李媛媛、高建平译, 商务印书馆 2006 年版。

[7] Liu Xiaofei and Yan Tianjie: Study of the Relationship between Art and Morality in the Perspective of Analytical Aesthetics. Philosophy Dynamics, Issue 5, 2010. 刘笑非、阎天洁: 《分析美学视野下的艺 术和道德关系研究》，《哲学动态》2010年第 5 期。

[8] [Ancient Greece] Aristotle: Nico Marco Ethics, Chinese Social Science Press, 1990 edition.【古希腊】亚里士多德: 《尼可马科伦理 学》, 中国社会科学出版社 1990 年版。 
[9] Lessing: Laocoon, translated by Zhu Guangqian, People's Literature Publishing House, 1984 edition. 莱辛: 《拉奥孔》, 朱光潜译, 人 民文学出版社 1984 年版。

[10] Complete Works of Wilde, Volume 4, edited by Zhao Wuping, Chinese Literature Publishing House, 2000 edition. 赵武平主编: 《王尔德全 集》第四卷, 中国文学出版社 2000 年版。

[11] [American] Mathay Karenescu: Five Faces of Modernity, translated by Gu Ailin and Li Ruihua, Commercial Press, 2002 edition. 【美】马 泰. 卡琳内斯库: 《现代性的五副面孔》, 顾爱林、李瑞华译, 商 务印书馆 2002 年版。 